\title{
VIGILANT® HERBICIDE FOR CONTROL OF TWO WILDING CONIFER SPECIES, CONTORTA PINE AND DOUGLAS FIR
}

\author{
M.J. NEWFIELD ${ }^{1}$ and B.G. WARD ${ }^{2}$ \\ ${ }^{1}$ Department of Conservation, Science \& Research Unit, PO Box 10420, Wellington \\ ${ }^{2}$ HortResearch, Ruakura Research Centre, Private Bag 3123, Hamilton \\ Corresponding author: mnewfield@doc.govt.nz
}

\begin{abstract}
Wilding conifers are usually killed without herbicide by severing the stem below the lowest green needles. This is difficult, for example, when multistemmed trees are growing on unstable or rocky substrates. Under such circumstances a picloram gel formulation (Vigilant ${ }^{\circledR}$ herbicide gel) was applied to freshly cut surfaces of stumps of contorta pine (Pinus contorta) and Douglas fir (Pseudotsuga menziesii). Stumps were pruned so that some green needles remained on the stump below the cut. Treatments were applied in May 2002. After 6 months, many herbicide-treated plants showed leaf distortion and yellowing. After 18 months, $97 \%$ of the 75 herbicide-treated contorta pine plants were dead compared with only $13 \%(n=30)$ of those receiving no herbicide. The herbicide killed $100 \%$ of the 15 treated Douglas fir plants compared with 3\% death rate for the 15 receiving no herbicide.
\end{abstract}

Keywords: herbicide, conifers, gel, contorta pine, Douglas fir.

\section{INTRODUCTION}

Control of wilding conifers is a major issue for New Zealand land managers, particularly in high country areas. Harding (2001) estimated that in the South Island over 210,000 ha of public conservation land was threatened by wilding conifers including contorta pine (Pinus contorta), Scots pine (Pinus sylvestris) and Douglas fir (Pseudotsuga menziesii). Control cost per annum is over $\$ 300,000$, even though not all the areas are controlled (Harding 2001).

A range of control techniques is used for wilding conifer control, with most techniques being non-herbicide (Ledgard 2004). The main methods in conservation areas are handpulling seedlings and felling larger trees. With the latter technique the "no green needles" approach, in which all green foliage is removed from a tree, must be used to kill the plant. This has been successful throughout New Zealand for many years, despite a lack of thorough research (Ledgard 2004).

If any green needles are left the tree will usually survive, and killing previously treated trees is harder than killing undamaged ones (J. Gilchrist, pers.comm.). In most instances the solution is good worker training. Nevertheless it can be difficult to achieve "no green needles". Where pines have established on unstable areas, such as screes, trees may be multi-leadered with green needles close to the ground or the leaves may be buried by scree. If the leaves are subsequently re-exposed this may allow the tree to recover. Cutting these trees at ground level is difficult and results in blunted chainsaw chains and poor control. The chainsaw operator is at increased risk and spends a lot of time trying to treat difficult trees. A stump treatment herbicide that allows the worker to spend less time cutting (by leaving some green needles) would be of great benefit.

A previous trial on stump treatment of wilding conifer species found sodium chlorate, ammonium sulfamate and glyphosate to be effective, with sodium chlorate the best (Crozier et al. 1988). Of these, only glyphosate is still registered in New Zealand (New Zealand Food Safety Authority 2004), and this treatment only killed $76.5 \%$ of trees 
growing at $1400 \mathrm{~m}$ (Crozier et al. 1988). Vigilant ${ }^{\circledR}(5 \%$ picloram as the potassium salt in a gel formulation) is a convenient and effective stump treatment for woody weeds (Ward \& Henzell 2004). It is widely used by Department of Conservation staff for the control of woody angiosperms, and is easy to carry and apply. It has not previously been tested on wilding conifer species. Tordon $\mathrm{K}$, a liquid formulation containing picloram as the potassium salt, has a label claim for Pinus spp. and Douglas fir as a spray but not a stump treatment (Dow Agrosciences 2004). This formulation is not available in New Zealand.

The objective of the work described in this paper was to determine the efficacy of Vigilant ${ }^{\circledR}$ herbicide applied as a stump treatment to contorta pine and Douglas fir under field conditions.

\section{METHODS}

A trial was conducted at Mount Morris, in the Branch Valley, Marlborough. The Branch Valley has extensive areas of wilding conifers resulting from an intensive planting programme in the 1960s and 1970s (Hayward \& Wishart 1975). Little wilding conifer control has been undertaken in this area (M. Brennan, pers. comm.). The trial site was at an altitude of 1400-1500 m, on thin rocky soil and with vegetation of wilding conifers and low-stature native species. Treatments were applied on 28 and 29 May 2001. The air temperature during application was $2-7^{\circ} \mathrm{C}$ with about $2 \mathrm{~cm}$ of snow on the ground, but snow cover varied considerably with degree of exposure. Treatment during the first day was interrupted by falling snow.

For the contorta pine trial, trees were grouped into 21 blocks of five trees, with blocks being at least $10 \mathrm{~m}$ apart along a path. Herbicide (15 blocks) and non-herbicide (6 blocks) treatments were randomly allocated to blocks before going into the field. All trees were cut with a chainsaw at a height ranging from $50 \mathrm{~mm}$ to $400 \mathrm{~mm}$ above the ground, leaving small $(<20 \mathrm{~mm})$ stems with green needles attached to the stump (from $1-15$ stems were left, with a mean of five per stump). The height of the cut stump and the diameters of cut and uncut stems were recorded to the nearest centimetre. For the herbicide treatment a 3-5 mm layer of Vigilant ${ }^{\circledR}$ was applied from the standard "brush bottle" to all cut surfaces (according to label directions), within 5 minutes of cutting. Trees that had no branches with green needles below the cut were excluded from the trial and the nearest suitable tree used as a replacement.

For the Douglas fir trial, plants were grouped into six blocks of five trees, with blocks being a minimum of $10 \mathrm{~m}$ apart. Herbicide (three blocks) and non-herbicide (three blocks) treatments were randomly allocated to the blocks. Cutting and herbicide applications were the same as for contorta pine trial. Again, cut height and number and size of cut stems were recorded, but not the size of uncut stems because of the growth pattern of Douglas fir. Although some Douglas fir trees had multiple stems, many had needles growing directly on the main stem.

Trials were assessed 6 months and 18 months after treatment. For each tree the number of live stems (with any green needles) and the condition of needles and wood were recorded. Needle condition classes for assessment were: (A) over 75\% green with new growth present; (B) 25-75\% green or yellow; (C) less than $25 \%$ green or yellow; (D) all brown and obviously dead. Wood condition was assessed and classified as dead (brown and dry just beneath the bark) or alive.

Surface areas of cut stems and the mean mortality of herbicide and non-herbicidetreated blocks were compared using Student's t-test (Fowler et al. 1998).

\section{RESULTS}

At the time of treatment, the surface area of cut stems (derived from diameter measurements) as a percentage of calculated surface area of both cut and uncut stems ranged from $22 \%$ to $99 \%$ for herbicide-treated and $25 \%$ to $99 \%$ for non-herbicidetreated plants, with no significant difference between the means $(\mathrm{P}>0.05)$. 
After 6 months many herbicide-treated contorta pine trees were unhealthy (needle condition B, C or D), but only two trees were classified as dead (needle condition D and wood condition dead). A further two trees had all their needles brown but the wood was still alive (Fig. 1). After 18 months all but two of the herbicide-treated trees were dead (i.e. needle condition $\mathrm{D}$ and wood dead), giving a mortality of $97 \%(\mathrm{n}=75)$. The two live trees had signs of new growth and were likely to survive. On examining the records from the time of treatment it was noted that the two surviving trees had had $22 \%$ and $81 \%$ of stem areas treated, while dead trees ranged from 36 to $99 \%$ of stem areas treated. Trees not treated with herbicide were mostly healthy (needle condition A) after 6 and 18 months ( $90 \%$ and $87 \%$ respectively with needle condition A), and after 18 months only four untreated trees had died (mortality of $13 \%, n=30$ ). The difference between the mortality of herbicide-treated and non-herbicide-treated trees was statistically significant $(\mathrm{P}<0.0001)$.

After 6 months, 13 of the 15 herbicide-treated Douglas fir were unhealthy (needle conditions B, C and D), but only two had died (Fig. 1). Six (out of 15) of those cut but with no herbicide were also unhealthy (needle condition B) after 6 months. After 18 months, all herbicide-treated Douglas fir had died; only one untreated plant had died, although seven untreated plants appeared unhealthy. The difference between the mortality of herbicide-treated and non-herbicide-treated trees was statistically significant $(\mathrm{P}<0.0001)$.
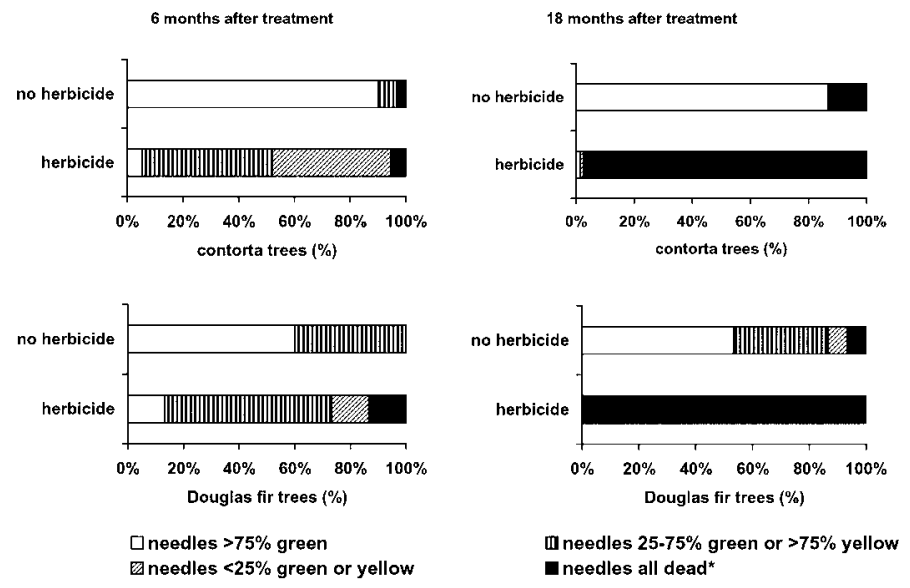

*after 6 months this does not necessarily indicate that the wood is also dead, but after 18 months if the neecles were all dead the wood was also dead

FIGURE 1: Needle condition of treated $(n=75)$ and untreated $(n=30)$ contorta pine
trees, and of treated $(n=15)$ and untreated $(n=15)$ Douglas fir trees,
after 6 and 18 months. The stumps of trees were treated with Vigilant ${ }^{\circledR}$
herbicide within 5 minutes of cutting the trunk with a chainsaw to
within $400 \mathrm{~mm}$ of the ground.

\section{DISCUSSION}

The results show that stump treatment with Vigilant ${ }^{\circledR}$ herbicide controls contorta pine and Douglas fir. The mortality of $97 \%$ for contorta pine in this trial is higher than rates reported for stump treatments on this species by Crozier et al. (1988), and it is consistent with results reported for Vigilant ${ }^{\circledR}$ on other species such as Cotoneaster simonsii $(97 \%, \mathrm{n}=30)$ and Berberis darwinii $(100 \%, \mathrm{n}=10)$ (Ward \& Henzell 2004). It is 
comparable to the mortality achieved on contorta pine by mechanical control $(100 \%$ if all green needles are removed). While the $100 \%$ kill rate for Douglas fir was only achieved on a small sample $(n=15)$, results were statistically significant, suggesting that the application of Vigilant ${ }^{\circledR}$ herbicide is a worthwhile technique for control of this species. While fewer blocks of both species were treated than originally planned, replication was still adequate.

In earlier stump treatment trials on contorta pine, sodium chlorate, ammonium sulfamate, 2,4-D and glyphosate were less effective on contorta pine at $1400 \mathrm{~m}$ than at $700 \mathrm{~m}$ altitude (Crozier et al. 1988). For sodium chlorate, mortality was $91 \%$ at $700 \mathrm{~m}$ and $86 \%$ at $1400 \mathrm{~m}$. For glyphosate, mortality was $96 \%$ at $700 \mathrm{~m}$, but $77 \%$ at $1400 \mathrm{~m}$. The $97 \%$ mortality for contorta pine with Vigilant ${ }^{\circledR}$ herbicide gel at $1400 \mathrm{~m}$ reported here is an excellent result.

A small number of native and exotic plants growing close to herbicide-treated plants showed symptoms of herbicide damage, such as leaf yellowing and growth distortion, or death. This damage probably resulted from herbicide dripping from the treated stems onto the ground, which was observed when marker tags were hammered into the treated trees. Non-target damage for the usual use of this technique is likely to be less than that observed in the trial.

The main limitations to the technique are the public desire to minimise herbicide use, especially in conservation areas (Williams 1997), and the cost of herbicide. The herbicide cost to treat the average-sized contorta pine in this study (average treated stem surface area of $112 \mathrm{~cm}^{2}$ ) was approximately $\$ 5$ (bulk retail cost, GST inclusive). This cost would not be offset by the time saved for most ground control operations for wilding conifers, but using the herbicide gel is advantageous where removing all green needles is difficult or dangerous. For operations where helicopters are used (at over $\$ 1000$ an hour) to access individual trees, a time saving of a few minutes per tree and the reduced need for retreatment would easily offset the herbicide cost.

\section{ACKNOWLEDGEMENTS}

We thank Willi Borst, Dave Hayes, Eric Hansen and Tavita Togia for help with the fieldwork, and John Gilchrist for help with field work and for sharing his extensive practical experience. Thanks also to Ian Popay for his help with methodology and manuscript.

\section{REFERENCES}

Crozier, L.R.; Zych, T.R.; Ledgard, N.J. 1988: Control of wilding conifers by applying herbicides to cut stumps. Proc. $41^{\text {st }}$ N. Z. Weed and Pest Control Conf.: 160-163.

Dow Agrosciences 2004: Specimen labels and Material Safety Data sheets. http:// www.dowagro.com/webapps/lit/litorder.asp?filepath=label/pdfs/noreg/01000095.pdf\&pdf=true $(03 / 05 / 04)$.

Fowler, J.; Cohen, L.; Jarvis, P. 1998: Practical statistics for field biology. John Wiley \& Sons, Chichester, England. 259 p.

Harding, M. 2001: South Island wilding conifer strategy. Department of Conservation, Christchurch, New Zealand. 54 p.

Hayward, J.D.; Wishart, C.J. 1975. A decade of revegetation work in Leatham State Forest, Nelson Conservancy. N. Z. For. Serv. Int. Rep. Available from Information Resource Centre, Department of Conservation, Wellington, New Zealand. 51 p.

Ledgard, N.J. 2004: Wilding conifers - New Zealand history and research background. In: Managing wilding conifers in New Zealand: present and future. Hill, R.L.; Zydenbos, S.M.; Bezar, C.M. ed. New Zealand Plant Protection Society, Lincoln, New Zealand. Pp. 1-25.

New Zealand Food Safety Authority 2004: Database of currently registered pesticides. http://www.nzfsa.govt.nz/acvm/registers-lists/pesticides/index.htm (25/03/04).

Ward, B.G.; Henzell, R.F. 2004: Use of herbicidal gels on woody weeds. DOC Science Internal Series 162. Department of Conservation, Wellington. $21 \mathrm{p}$.

Williams, J.M. 1997: Maintaining the health of ecosystems in the $21^{\text {st }}$ century: the challenges facing plant protection sciences, industry and users. Proc. $50^{\text {th }} \mathrm{N}$. Z Weed and Pest Control Conf: : 486-492. 